\title{
Social and Moral Relationships with Robots: Genetic Epistemology in an Exponentially Increasing Technological World
}

\author{
Peter H. Kahn, Jr. Heather E. Gary Solace Shen \\ University of Washington, Seattle, Wash., USA
}

It has been happening for centuries. New technologies are invented that reshape individual thought and restructure social life. The emergence of the printing press, for example, provided access to written language for millions of people. In so doing, it gave rise to new forms of mental representations and to a powerful new means for the accretion of knowledge across generations.

We would like to suggest that an equally astonishing technology is on the immediate horizon: social embodied technological networked entities. For purposes here we will narrow the class of these entities to perhaps their most canonical form: social robots. These robots embody aspects of people insofar as they have a persona, are adaptive and autonomous, and can talk, learn, use natural cues, and self-organize. One such humanoid robot, Robovie, was used as a museum guide at the Osaka Science Museum in Japan, and autonomously led groups of children around the museum, and conversed with them [Shiomi, Kanda, Ishiguro, \& Hagita, 2007]. In the near future, think of a child coming home from school and interacting with a robot nanny or a robot friend [Tanaka, Cicourel, \& Movellan, 2007]. Or think of an elderly person who is assisted in the home by a robot caretaker and who finds company through interaction with the robot [Sparrow \& Sparrow, 2006]. Or, building conceptually on early software programs like ELIZA [Weizenbaum, 1966], think of patients in sessions with a robot therapist. These scenarios are not just science fiction any more. They are in research laboratories and will soon emerge in common life.

These robots will not only change our everyday lives but the way we think about what constitutes a social and moral other.

We've been finding this to be so in our collaborative research. In one study, for example, 90 children (9-, 12-, and 15-year-olds) initially interacted with the humanoid robot Robovie in 15-minute sessions [Kahn et al., 2012a]. Each session ended when an experimenter interrupted Robovie's turn at a game and, against Robovie's stated moral objections - based on moral considerations of fairness and psychological harm to itself - put Robovie into a closet. Each child was then engaged in a

\begin{tabular}{ll}
\hline KARGER & ( ) 2013 S. Karger AG, Basel \\
0018-716X/13/0561-0001\$38.00/0 \\
$\begin{array}{ll}\text { Fax +41 61 306 12 34 } \\
\text { www.karger.com }\end{array}$ & $\begin{array}{l}\text { Accessible online at: } \\
\text { www.karger.com/hde }\end{array}$
\end{tabular}

Peter H. Kahn

Department of Psychology, University of Washington Box 351525

Seattle, WA 98195-1525 (USA)

E-Mail pkahn@u.washington.edu 
50-minute structural-developmental interview. Results showed that, during the interaction sessions, all of the children engaged in physical and verbal social behaviors with Robovie. Based on the interview data, the majority of children believed that Robovie had mental states (e.g., was intelligent and had feelings) and was a social being (e.g., could be a friend, offer comfort, and be trusted with secrets). In terms of Robovie's moral standing, the majority of children believed that Robovie deserved fair treatment and should not be harmed psychologically.

Our interviews were extensive, and following in the tradition established by $\mathrm{Tu}$ riel and his colleagues [Killen, 1990; Nucci, 2001; Smetana, 2006; Turiel, 1983], we assessed moral reasoning through criterion judgments and moral justifications. In data analysis, we created a composite score that comprised (a) a prescriptive judgment ('it's not all right to have put Robovie in the closet'), (b) which generalized ('it's not all right for people in another country to have put Robovie in the closet even if that's the way they do things there'), and (c) was supported by a moral justification such as fairness (e.g., 'I don't think it was right because we were in the middle of a game, and so it wasn't fair to him'). To be coded as domain-specific moral reasoning, a child needed to meet all 3 conditions. Based on these stringent moral criteria, results showed that $31 \%$ of the children provided domain-specific moral reasoning about not putting Robovie in the closet. As the basis for comparison, $74 \%$ provided domain-specific moral reasoning about not putting a human in the closet in a similar situation. We highlight these domain-specific moral results to counter a potential concern that we are being led astray by superficial reasoning about social robots that only tangentially looks 'moral' but isn't.

That said, people's moral reasoning about Robovie does not appear to map on to how people reason morally about other people. For example, in the above study, the children and adolescents did not believe that Robovie was entitled to its own liberty (Robovie could be bought and sold) or civil rights (in terms of voting rights and deserving compensation for work performed). Moreover, in another study, we had Robovie cause a small harm to 40 adult participants [Kahn et al., 2012b]. Results showed that on the whole participants held Robovie less accountable morally than they would a human but more accountable than they would a machine.

What we are suggesting, then, is this: people will bring moral reasoning to bear in their relationships with social robots of the near future. People will grant these social robots moral standing in some ways and hold them partly morally accountable. But structurally, people's moral reasoning about robots will be different from their moral reasoning about other people.

If we are right about this, then we would like to propose - and conclude with - 3 large issues for consideration.

(1) Human Well-Being and Flourishing. If increasingly sophisticated and life-like social robots come to substitute substantially for human-human interaction, will there be an objectification of the social 'other' that leads to detrimental outcomes for children and adults? For example, if it is true that the reciprocity embedded in peerpeer interaction is essential for children's moral development [Kohlberg, 1969; Piaget, 1932/1969; Turiel, 1983], then can that mechanism occur in human-robot interaction, where the social other is a technology? Consider when sex dolls, with very life-like forms, become social robots and are designed to do people's sexual bidding. Will that diminish the depth of adult reciprocity and human intimacy? Consider when robot warriors take the place of people on the battlefield (as drones partly do$$
2
$$ 
now). There is currently a 26-billion-dollar initiative by the US Government to transform US warfare more into robotic warfare [Gertler, 2012]. Will that distance us from human suffering and killing others and make war more likely?

(2) Genetic Epistemology and the New Ontological Category Hypothesis. Piaget argued that knowledge does not exist 'out there' in some reified form to be discovered (nor is it a nativistic property of the human mind) but that children construct knowledge through interaction with a physical and social world. It is in this sense that Piaget [1971] developed his account of genetic epistimology and argued that a valid philosopy depended on a valid psychology and its ontogenesis. This position is not too different from what some moral philosophers have argued: that while is does not imply ought, ought does imply can, and that a valid moral philosophy needs to be concordant with a valid moral psychology [Scheffler, 1992]. But now here's the rub. During the last 150 years, with the advent of modern psychology, the physical and social world has stayed relatively stable over the career spans of psychologists conducting investigations. That's not the case anymore. We believe that, with the emergence of these social robots (and, more generally, social embodied technological networked entities, which will include personfied, responsive, autonomous cars and homes of the future), a new ontological category is emerging, one that is technologically alive. What we're seeing now is the onset of children's construction of knowledge of this new category of being [Kahn et al., 2011, 2012a; Kahn, Friedman, \& Hagman, 2002; Kahn, Gary, \& Shen, in press].

(3) An Exponentially Increasing Technological World. Kurzweil [2005] convincingly argues that the rate of technological change is increasing exponentially. To illustrate exponential growth, take a dollar and double it every day. After a week, you have $\$ 64$, which is hardly much to shout about. After a month you have over a billion dollars. Kurzweil shows that we are at the 'knee' of that exponential curve where technological growth has begun to accelerate at an increasingly astonishing rate. Thus, in our respective disciplines, we all need to be agile and future-oriented in our investigations of how technology will change not only social systems but what we as humans think and how we think.

\section{References}

Gertler, J. (2012). U.S. unmanned aerial systems. Washington: Congressional Research Service, Library of Congress.

Kahn, P.H., Jr., Friedman, B., \& Hagman, J. (2002). 'I care about him as a pal': Conceptions of robotic pets in online AIBO discussion forums. In Extended abstracts of the conference on human factors in computing systems (pp. 632-633). New York: Association for Computing Machinery.

Kahn, P.H., Jr., Gary, H.E., \& Shen, S. (in press). Children's social relationships with current and nearfuture robots. Child Development Perspectives.

Kahn, P.H., Jr., Kanda, T., Ishiguro, H., Freier, N.G., Severson, R.L., Gill, B.T., Ruckert, J.H., \& Shen, S. (2012a). 'Robovie, you'll have to go into the closet now': Children's social and moral relationships with a humanoid robot. Developmental Psychology, 48, 303-314.

Kahn, P.H., Jr., Kanda, T., Ishiguro, H., Gill, B.T., Ruckert, J.H., Shen, S., Gary, H., Reichert, A.L., Freier, N.G., \& Severson, R.L. (2012b). Do people hold a humanoid robot morally accountable for the harm it causes? In Proceedings of the 7th ACM/IEEE international conference on human-robot interaction (pp. 33-40). New York: Association for Computing Machinery.

Kahn, P.H., Jr., Reichert, A.L., Gary, H.E., Kanda, T., Ishiguro, H., Shen, S., Ruckert, J.H., \& Gill, B. (2011). The new ontological category hypothesis in human-robot interaction. In Proceedings of the 6th ACM/IEEE international conference on human-robot interaction (pp. 159-160). New York: Association for Computing Machinery. 
Killen, M. (1990). Children's evaluations of morality in the context of peer, teacher-child and familial relations. Journal of Genetic Psychology, 151, 395-410.

Kohlberg, L. (1969). Stage and sequence: The cognitive-developmental approach to socialization. In D.A. Goslin (Ed.), Handbook of socialization theory and research (pp. 347-480). New York: Rand McNally.

Kurzweil, R. (2005). The singularity is near. New York: Viking.

Nucci, L.P. (2001). Education in the moral domain. New York: Cambridge University Press.

Piaget, J. (1969). The moral judgment of the child. Glencoe: Free Press (original work published 1932).

Piaget, J. (1971). Genetic epistemology. New York: Norton.

Scheffler, S. (1992). Human morality. New York: Oxford University Press.

- Shiomi, M., Kanda, T., Ishiguro, H., \& Hagita, N. (2007). Interactive humanoid robots for a science museum. IEEE Intelligent Systems, 22, 25-32.

Smetana, J.G. (2006). Social domain theory: Consistencies and variations in children's moral and social judgments. In M. Killen \& J.G. Smetana (Eds.), Handbook of moral development (pp. 119-154). Mahwah: Erlbaum.

Sparrow, R., \& Sparrow, L. (2006). In the hands of machines? The future of aged care. Minds and Machines, 16, 141-161.

Tanaka, F., Cicourel, A., \& Movellan, J.R. (2007). Socialization between toddlers and robots at an early childhood education center. Proceedings of the National Academy of Sciences of the United States of America, 104, 17954-17958.

Turiel, E. (1983). The development of social knowledge. Cambridge: Cambridge University Press.

-Weizenbaum, J. (1966). ELIZA - A computer program for the study of natural language communication between man and machine. Communications of the ACM, 9, 36-45. 